\title{
The polyamine diaminodecane (DA-10) produces a voltage-dependent flickery block of single NMDA receptor channels
}

\author{
David M. Rock ${ }^{\mathrm{a}, 1}$ and Robert L. Macdonald ${ }^{\mathrm{b}}$ \\ ${ }^{a}$ Neuroscience Program and ${ }^{b}$ Departments of Neurology and Physiology, University of Michigan, Ann Arbor, MI (USA)
}

(Received 31 January 1992; Revised version received 30 April 1992; Accepted 15 June 1992)

Key words: $\quad N$-Methyl-D-aspartate; Patch clamp; Single channel; Polyamine; Inverse agonist

\begin{abstract}
Receptor binding assays have shown that diaminodecane (DA-10) reduced binding of open channel blockers to the $N$-methyl-D-aspartate (NMDA) subtype of postsynaptic glutamate receptor through an interaction with the polyamine regulatory site. Because the action of DA-10 was opposite to that of the polyamine agonist spermine and was reversed by polyamine antagonists, DA-10 has been classified as an inverse agonist at the polyamine site. Using whole-cell voltage-clamp and single-channel recordings from cultured rat cortical neurons, we show that at negative holding potentials DA-10 $(1-300 \mu \mathrm{M})$ reduced NMDA receptor whole cell current $\left(\mathrm{IC}_{50}=34 \mu \mathrm{M}\right)$ and produced a flickery block of NMDA single-channel currents. The flickery block of NMDA single channels was voltage-dependent and not reversed by the polyamine antagonist diethylenetriamine (DET). Potential mechanisms for the flickery block of NMDA single channel currents are discussed.
\end{abstract}

The $N$-methyl-D-aspartate (NMDA) subtype of postsynaptic glutamate receptor has been shown to be important in a variety of physiological and pathophysiological conditions $[2,11,19]$. The NMDA receptor ion channel complex has several regulatory sites, including a site at which polyamines act with to regulate binding of open channel blockers to the NMDA receptor [11, 19].

Diaminodecane (DA-10), a ten carbon straight chain molecule with terminal amine groups, reduced binding of open channel blockers to the NMDA subtype of postsynaptic glutamate receptor and displaced binding of $\left[{ }^{3} \mathrm{H}\right]$ spermidine from a low affinity site in rat cortical membranes [7, 18-20]. The DA-10 reduction of open channel blocker binding was reversed by the polyamine antagonist diethylenetriamine (DET) [18] and was opposite to the action of the polyamine agonist spermine [13, $15,18,20]$. Therefore, DA-10 has been classified as an inverse agonist at the polyamine site.

Voltage-clamp recordings from cultured CNS neurons and poly $(\mathrm{A})^{+}$mRNA-injected frog oocytes have shown that the polyamine agonists spermine and spermidine enhanced NMDA receptor currents $[9,10,14,16,18]$. DA10 reduced NMDA receptor current $[9,18]$, and the re-

'Present address: Pharmacology Department, Parke-Davis Research, 2800 Plymouth Rd, Ann Arbor, MI 48106-1047, USA.

Correspondence: R.L. Macdonald, Neuroscience Laboratory Building, 1103 East Huron, Ann Arbor, MI 48104-1687, USA. duction of NMDA receptor current by DA-10 was reversed by the polyamine antagonist DET [18].

We have previously shown that the polyamine agonist spermine had multiple effects on NMDA receptor single channels [14]. Therefore, the following studies using whole-cell voltage-clamp and single-channel recording techniques were carried out to investigate the effect of DA-10 on NMDA receptor currents and to compare the effect of DA-10 with that of SP.

Methods for these experiments were essentially identical to those outlined in Rock and Macdonald [14]. Briefly, cultures of fetal rat cortical neurons were prepared by standard methods and whole-cell voltageclamp and single-channel recordings were obtained using procedures similar to Hamill et al. [5].

The same external and internal solutions were used for whole-cell voltage-clamp and excised outside-out singlechannel recordings. The external solution consisted of (in $\mathrm{mM}): \mathrm{NaCl} 142, \mathrm{KCl} 1.5, \mathrm{CaCl}_{2} 1$, glucose $10, \mathrm{Na}-$ HEPES 10 ( $\mathrm{pH} 7.4$ ), $0.5 \mu \mathrm{M}$ glycine, $0.2 \mu \mathrm{M}$ strychnine, $0.5 \mu \mathrm{M}$ tetrodotoxin (added for whole cell recordings). Osmolarity was adjusted to $320 \mathrm{mOsm}$ by the addition of sucrose. The internal pipette solution consisted of: 153 $\mathrm{mM} \mathrm{CsCl}, 10 \mathrm{mM}$ Cs-HEPES, 5 mM EGTA (pH 7.4). Osmolarity was adjusted to $305 \mathrm{mOsm}$ with water. Chemicals and drugs were obtained from Sigma Chemical Co (St. Louis, MO).

NMDA and glycine were dissolved in saline or exter- 
nal solution. DA-10 was dissolved in saline with the addition of $1 \mathrm{~N} \mathrm{HCl}$. Stock solutions were made up at concentrations between $10 \mathrm{mM}$ and $100 \mathrm{mM}$ and serially diluted to final concentrations.

Drugs were applied to whole cells or patches by pressure ejection $(0.25-1.0 \mathrm{psi})$ from blunt tipped (15-25 $\mu \mathrm{m})$ glass micropipettes positioned within $50 \mu \mathrm{m}$ of the cell or patch.

Whole-cell and single-channel recordings were performed with a L/M EPC-7 amplifier (LIST-Medical Instruments) and currents were recorded on a video cassette system via a digital audio processor (PCM II, Medical Systems, Inc., 16 bit, $44 \mathrm{kHz}$ ). Currents were simultaneously displayed on a chart recorder (Gould Inc.) using a lowpass $(-3 \mathrm{~dB}$ at $1 \mathrm{kHz}$ ) eight-pole Bessel filter (Frequency Devices). For single channel analysis, the data were played back from the video cassette system through a lowpass filter $(-3 \mathrm{~dB}$ at $2 \mathrm{kHz})$ and digitized (20 kHz, 12 bit, Tecmar A/D converter) for computer analysis. System dead time was $70 \mu \mathrm{s}$. Openings greater than $140 \mu$ s (two times the system dead time) were considered valid openings.

Single-channel data were analyzed by computer using a locally written channel detection program ( $50 \%$ threshold crossing criterion) and locally written analysis programs were used to determine opening frequency, burst frequency, burst duration, open duration and closed duration by methods described previously [8]. Although NMDA has been shown to activate a channel or channels with several conductance levels $[3,4,6]$, openings were predominantly of $50 \mathrm{pS}$ conductance. In this study, openings from the two higher conductance levels ( 40 and $50 \mathrm{pS}$ ) were analyzed. The amplitudes of the higher con-

\section{$5 \mu \mathrm{M}$ NMDA}

$.75 \mathrm{mV}$

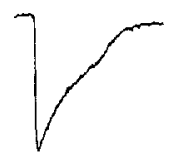

$\int_{+75 \mathrm{mV}}$

Fig. 1. DA-10 blocked NMDA receptor current in a voltage-dependent manner. Upper trace shows reduction of $5 \mu \mathrm{M}$ NMDA receptor current by the addition of 10 and $100 \mu \mathrm{MDA}-10$ at a holding potential of $-75 \mathrm{mV}$. NMDA or NMDA plus DA-10 were applied for $5 \mathrm{~s}$. Lower trace shows that the effect of $100 \mu \mathrm{M}$ DA- 10 on $5 \mu \mathrm{M}$ NMDA receptor current at a holding potential of $+75 \mathrm{mV}$ was not as pronounced. Data were taken from the same cell.

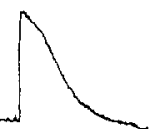

ductance levels were determined from amplitude histograms (IPROC and PSTAT, Axon Instruments).

Bursts are defined as groups of openings that are separated by long closures. For this analysis a critical closed time $\left(t_{\mathrm{c}}\right)$ was chosen such that all openings separated by closures shorter than this $t_{\mathrm{c}}$ were considered to belong to a burst. A modification of the equal proportion of misclassification method [8] was used to select a $t_{\text {. }}$ of $15 \mathrm{~ms}$.

DA-10 produced a voltage-dependent reduction in NMDA receptor current. At a holding potential of -75 $\mathrm{mV}, \mathrm{DA}-10(1-300 \mu \mathrm{M})$ reduced NMDA receptor current with an $\mathrm{IC}_{51}$ of $34 \mu \mathrm{M}$ (Fig. 1). DA-10 $(100 \mu \mathrm{M})$ reduced NMDA receptor current by $69 \%( \pm 2.8, n=8)$ at a holding potential of $-75 \mathrm{mV}$, but only reduced NMDA receptor current by $24 \%( \pm 1.1, n=4)$ at a holding potential of $+75 \mathrm{mV}$ (Fig. 1).

DA-10 produced a flickery block of NMDA receptor single-channel currents at negative holding potentials. NMDA $(5 \mu \mathrm{M})$ produced openings with an average open duration of $4.5 \mathrm{~ms}$ that were organized in bursts that had an average duration of $16.9 \mathrm{~ms}$ (Fig. $2 \mathrm{~A}$, Table I). Addition of $1(n=4), 10(n=5), 30(n=5)$ or $100 \mu \mathrm{M}(n=12)$ DA-10 produced a flickery block of NMDA receptor
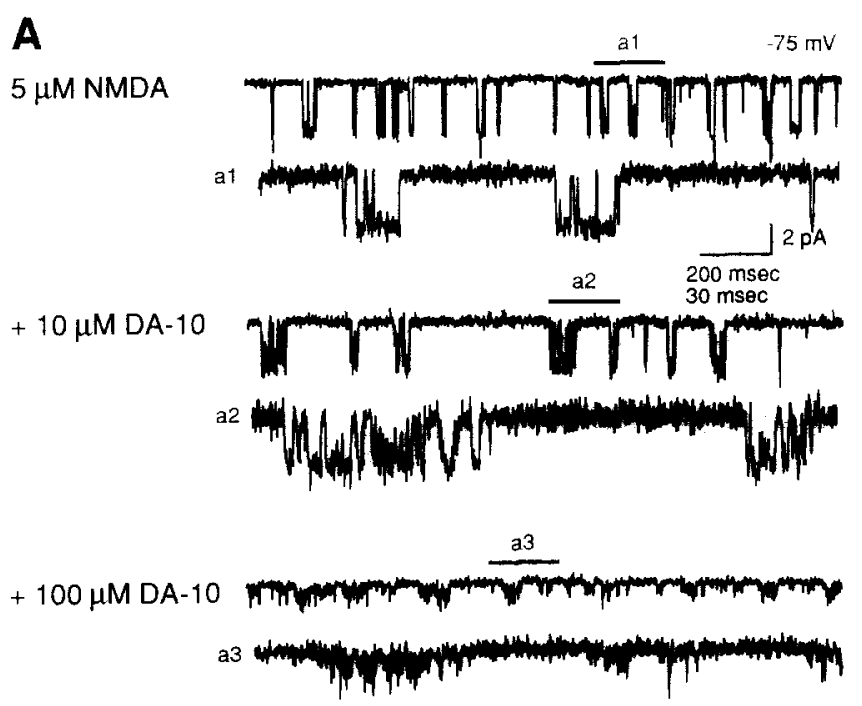

B

$5 \mu \mathrm{M}$ NMDA

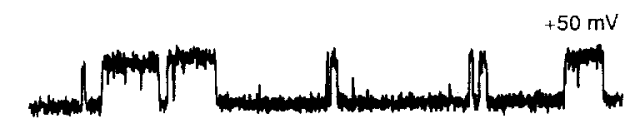

$+100 \mu \mathrm{M} D A-10$

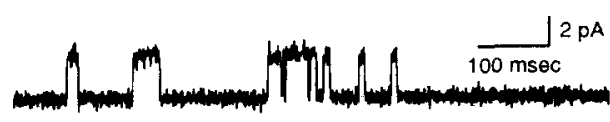

Fig. 2. DA-10 caused a voltage-dependent flickery block of single NMDA channels. A: NMDA ( $5 \mu \mathrm{M})$ applied to an excised outside-out patch produced openings that were organized into bursts (upper pair of traces) at a holding potential of $-.75 \mathrm{mV}$. Addition of 10 and $100 \mu \mathrm{M}$ DA-10 (middle and lower pairs of traces) caused a concentration-dependent block of NMDA receptor single channels. B: at a holding potential of $+50 \mathrm{mV}$. DA- $10(100 \mu \mathrm{M})$ did not block NMDA receptor single-channel openings produced by $5 \mu \mathrm{M}$ NMDA 
TABLE I

EFFECT OF DA-10 ON SINGLE CHANNEL KINETIC PARAMETERS OF NMDA-EVOKED SINGLE CHANNEL CURRENTS

Numbers in parentheses are the number of openings or bursts that the average durations are based on.

\begin{tabular}{|c|c|c|c|c|}
\hline & $N$ & $\begin{array}{l}\text { Main state amp. } \\
(\mathrm{pA})\end{array}$ & $\begin{array}{l}\text { Average open duration } \\
\text { (ms) }\end{array}$ & $\begin{array}{l}\text { Average burst duration } \\
\text { (ms) }\end{array}$ \\
\hline \multicolumn{5}{|l|}{$-75 \mathrm{mV}$} \\
\hline $5 \mu \mathrm{M}$ NMDA & 6 & 3.3 & $\begin{array}{l}4.51 \\
(5439)\end{array}$ & $\begin{array}{l}16.9 \\
(2004)\end{array}$ \\
\hline$+1 \mu \mathrm{M} \mathrm{DA}-10$ & 4 & 3.3 & $\begin{array}{l}3.30 \\
(7211)\end{array}$ & $\begin{array}{l}18.1 \\
(1899)\end{array}$ \\
\hline$+10 \mu \mathrm{M}$ DA- 10 & 5 & 2.8 & $\begin{array}{l}1.16 \\
(16873)\end{array}$ & $\begin{array}{l}21.0 \\
(2189)\end{array}$ \\
\hline \multicolumn{5}{|l|}{$+50 \mathrm{mV}$} \\
\hline $5 \mu \mathrm{M}$ NMDA & 3 & 2.9 & $\begin{array}{l}10.01 \\
(922)\end{array}$ & $\begin{array}{l}20.4 \\
(517)\end{array}$ \\
\hline$+100 \mu \mathrm{M} \mathrm{DA}-10$ & 3 & 2.9 & $\begin{array}{l}8.30 \\
(1493)\end{array}$ & $\begin{array}{l}20.7 \\
(737)\end{array}$ \\
\hline
\end{tabular}

single-channel currents at a holding potential of $-75 \mathrm{mV}$ (Figs. 2A and 3, Table I). Because of the reduction in duration and amplitude of resolved single channel openings at concentrations of DA-10 of $30 \mu \mathrm{M}$ and above, analysis of the effect of DA-10 on kinetic parameters of single channel openings was done at lower concentrations ( 1 and $10 \mu \mathrm{M})$.

The block of NMDA single channel current by DA-10 was characterized by an increase in opening frequency ( $280 \pm 62 \%$ control, $n=5$ for $10 \mu \mathrm{M} \mathrm{DA}-10$ ), a decrease in average open duration and an increase in burst duration (Table I). The burst frequency was unaffected by addition of DA-10 ( $120 \pm 21 \%$ control, $n=5$ for $10 \mu \mathrm{M} \mathrm{DA}-$ $10)$. Since the percent reduction in average open duration (Table I) was greater than the percent increase in opening frequency, the net effect of $10 \mu \mathrm{M}$ DA-10 was a $22 \%$ decrease in current through NMDA receptor single channels compared to control. Higher concentrations of DA- 10 resulted in greater reductions (53\% decrease at 30 $\mu \mathrm{M}$ and $94 \%$ decrease at $100 \mu \mathrm{M}$ ) of current through NMDA receptor single channels.

The effect of DA-10 on average open duration was voltage dependent. At a holding potential of $+50 \mathrm{mV}$, DA-10 $(100 \mu \mathrm{M})$ had only a small effect on average open duration (17\% reduction) and had no effect on the other single channel kinetic parameters ( $n=3$, Fig. 2B, Table I).

The flickery block of NMDA receptor single-channel currents caused by DA-10 was not reversed by the polyamine antagonist DET. Additon of $100 \mu \mathrm{M}$ DET caused a $10 \%$ reduction in the amplitude of NMDA receptor currents without an apparent production of flickery channel block (Fig. 3). Addition of DET (n=4) did not reverse the flickery block of NMDA single channel currents caused by $30 \mu \mathrm{M} \mathrm{DA}-10$ (Fig. 3).

DA-10 reduced NMDA receptor whole cell currents, and at the same concentrations produced a flickery block of NMDA single channel currents. Both effects of DA10 were voltage dependent, being reversed by membrane or patch depolarization. It is likely that the flickery block of NMDA single channel currents underlies the effect of DA-10 on whole cell currents.

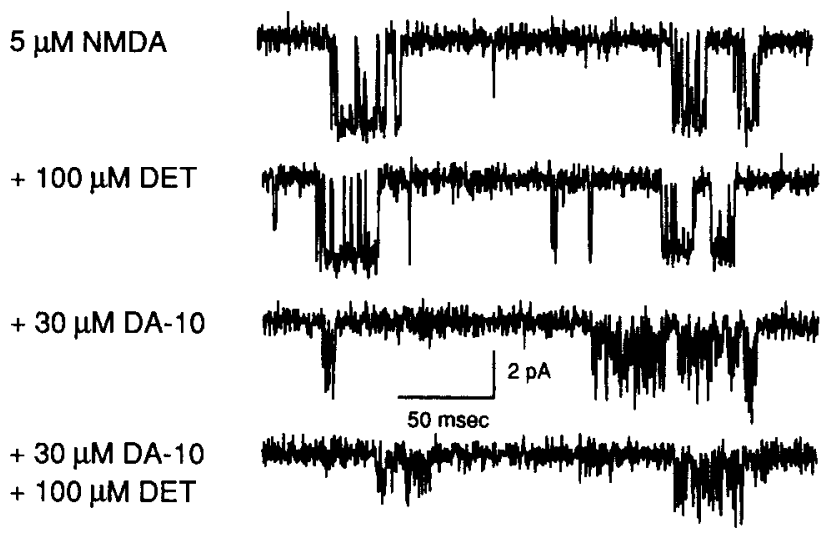

Fig. 3. The block of NMDA receptor single-channel currents by DA-10 was not reversed by the polyamine antagonist diethylenetriamine (DET). Application of $5 \mu \mathrm{M}$ NMDA to an excised outside-out patch (first trace) produced openings with an amplitude of around $3.5 \mathrm{pA}$ at a holding potential of $-75 \mathrm{mV}$. Addition of DET $(100 \mu \mathrm{M})$ reduced the amplitude of the openings by a small amount (10\%) (second trace). Addition of DA-10 (30 $\mu \mathrm{M})$ caused a flickery block of NMDA singlechannel currents (third trace). The combination of DET and DA-10 caused a flickery block of NMDA receptor single-channel currents but with a reduced amplitude (fourth trace). 
DA-10 altered single channel kinetic parameters. While opening frequency and burst duration of NMDA receptor single channel currents increased, average open duration decreased. Since the percent decrease in average open time was greater than the percent increase in opening frequency, the net effect of DA-10 was reduction in current through NMDA receptors. These effects on single channel parameters were similar to the effect of $\mathrm{Mg}^{2+}$ on NMDA receptors [1], local anesthetics on nicotinic acetylcholine receptors [12], and penicillin on $\mathrm{GABA}_{\mathrm{A}}$ receptor [17] suggesting that the mechanism of the DA10-induced reduction of NMDA receptors may be fast open channel block.

The pharmacology of the effect of DA-10 on NMDA receptor currents was not consistent with an interaction with the polyamine site. The flickery channel block produced by DA-10 was not reversed by the polyamine antagonist DET. In fact, DET caused a further reduction of current through the NMDA receptor channels. The flickery channel block by DA-10 was not similar to actions of the polyamine agonist spermine on NMDA receptor single channels currents [14]. At low concentrations spermine increased the opening and burst frequency of NMDA single channel currents without affecting other single channel parameters [14]. DA-10 also increased opening frequency but had no effect on burst frequency and reduced average open duration of NMDA single channel currents. The effect of DA-10 on opening frequency may be due to increased closures during bursts leading to increased number of openings, an effect unrelated to the effect of spermine on opening frequency. High concentrations of spermine also reduced NMDA receptor conductance. This effect of spermine was not due to a flickery channel block of NMDA receptor currents [14] like DA-10. These data suggest that the action of DA-10 on NMDA receptor single channels may not be due to an action solely at the polyamine binding site.

The open channel block of NMDA receptor single channels by DA-10, however, may explain some of the results in receptor binding assays. The effects of polyamines on NMDA receptors in receptor binding assays have been quantified by measuring effects on the binding of open channel blockers to the NMDA receptor $[13,15$, 18-20]. Since the flickery channel block of DA-10 of NMDA receptor single channel currents occurred over the same concentration range $(1-100 \mu \mathrm{M})$ as reduction of open channel blocker binding by DA-10, it is possible that DA-10 may reduce the binding of open channel blockers by occluding the channel opening or competing for a similar site inside the pore of the channel.

These experiments indicate that DA-10 produced an open channel block of NMDA receptor single channels that may explain the effects seen on NMDA whole cell receptor current and in receptor binding assays. This flickery block of NMDA single channels may not be due to an action at the polyamine regulatory site on the NMDA receptor and, in light of these results, the idea that DA-10 is an inverse agonist acting at the polyamine site should be reevaluated.

The authors wish to thank Mr. Gregory Campbell and Mr. Sean Hanson for preparation and maintenance of cell cultures. We also wish to thank Dr. Roy Twyman for assistance with data analysis and for useful comments on this manuscript. This work was supported by the USPHS Grant NS19613 to R.L.M.

1 Ascher. P. and Nowak. L.. The role of divalent cations in the $\mathrm{N}$ methyl-D-aspartate responses of mouse central neurons, J. Physiol., 399 (1988) $247-266$.

2 Choi, D.W., Glutamate neurotoxicity and diseases of the nervous system, Neuron, 1 (1988) 623.634.

3 Cull-Candy. S.G. and Usowicz, M.M., Multiple-conductance channels activated by excitatory amino acids in cerebellar neurons, $\mathrm{Na}$ ture, 325 (1987) $525-528$.

4 Cull-Candy, S.G. and Usowicz, M.M., On the multiple-conductance single channels activated by excitatory amino acids in large cerebellar neurons of the rat, J. Physiol., 415 (1989) $555-582$.

5 Hamill, O.P., Marty, A., Neher, E., Sakmann, B. and Sigworth, F.J.. Improved patch-clamp techniques for high resolution current recording from cells and cell-free membrane patches. Pflügers Arch., 391 (1981) 85 100.

$6 \mathrm{Jahr}$, C.E. and Stevens, C.F., Glutamate activates multiple single channel conductances in hippocampal neurons, Nature, 325 (1987) 522-525.

7 London, E.D., Dawson, V.L. and Mantione, C.R., Specific binding sites for polyamines in mammalian brain. In T. Kameyama, T. Nabeshima and E.F. Domino (Eds.), NMDA Receptor Related Agents: Biochemistry, Pharmacology and Behavior. NPP Books, Ann Arbor, 1991.pp. $71-78$.

8 Macdonald, R.L.. Rogers, C.J. and Twyman, R.E., Kinetic properties of the $\mathrm{GABA}_{\mathrm{A}}$ receptor main conductance state of mouse spinal cord neurones in culture, J. Physiol., 410 (1989) 479499.

9 Maciver, C.R., Bednar, D.L. and Karbon, W., Opposite effects of spermine and arcaine on responses of $\mathrm{N}$-methyl-1)-aspartate receptors expressed in Xenopus oocytes, Neurosci. Lett.. 132 (1991) 146. 150.

10 McGurk, J.F.. Bennett. M.L.V. and Zukin, R.S.. Polyamines potentiate the responses of $N$-methyl-D-aspartate receptors expressed in Xenopus oocytes, Proc. Natl. Acad. Sci. USA. 87 (1990) 9971 9974.

11 Monaghan, D.T., Bridges, R.J. and Cotman, C.W., The excitatory amino acid receptors: their classes, pharmacology, and distinct properties in the function of the central nervous system, Annu. Rev. Pharmacol. Toxicol., 29 (1989) 345 402.

12 Neher, E. and Steinbach. J.H., Local anaesthetics transiently block currents through single acetylcholine-receptor channels, J. Physiol. 277 (1978) 153-176.

13 Ransom, R.W. and Stec, N.L., Cooperative modulation of ['H]MK-801 binding to the $N$-methyl-D-aspartate receptor-ion channel complex by L-glutamate, glycine, and polyamines, J. Neurochem., 51 (1988) 830-836. 
14 Rock, D.M. and Macdonald, R.L., The polyamine spermine has multiple actions on $N$-methyl-D-aspartate receptor single-channel currents in cultured cortical neurons, Mol. Pharmacol., 41 (1992) 83-88.

15 Sacaan, A.I. and Johnson, K.M., Characterization of the stimulatory and inhibitory effects of polyamines on $\left[{ }^{3} \mathrm{H}\right] N-$ (1-[thienyl]cyclohexyl)piperidine binding to the $N$-methyl-D-aspartate receptor ionophore complex, Mol. Pharmacol., 37 (1990) 572-577.

16 Sprosen, T. and Woodruff, G.N., Polyamines potentiate NMDA induced whole-cell currents in cultured striatal neurons, Eur. J. Pharmacol., 179 (1990) 477-478.

17 Twyman, R.E., Green, R.M. and Macdonald, R.L., Kinetics of open channel block of single $\mathrm{GABA}_{\mathrm{A}}$ receptor channels by penicillin, J. Physiol., 455 (1992) 97-128.
18 Williams, K., Dawson, V.L., Romano, C., Dichter, M.A. and Molinoff, P.B., Characterization of polyamines having agonist, antagonist and inverse agonist effects at the polyamine recognition site of the NMDA receptor, Neuron, 5 (1990) 199-208.

19 Williams, K., Romano, C., Dichter, M.A. and Molinoff, P.B., Modulation of the NMDA receptor by polyamines, Life Sci., 48 (1991) 469498 .

20 Williams, K., Romano, C. and Molinoff, P.B., Effects of polyamines on the binding of $\left[{ }^{3} \mathrm{H}\right] \mathrm{MK}-801$ to the $N$-methyl-D-aspartate receptor: pharmacological evidence for the existence of a polyamine recognition site, Mol. Pharmacol., 36 (1989) 572-577. 